\title{
Rooting Reflex
}

National Cancer Institute

\section{Source}

National Cancer Institute. Rooting Reflex. NCI Thesaurus. Code C81320.

An involuntary, primal response in the neonate to search for the nipple when the cheek is touched. 